\title{
The Role of Customer Relationship Management in Enhancing the Mental Image of the Saudi Telecom Company (STC): A Field Study of STC Customers
}

\author{
Dr. Mansour Abdullah Almiman \\ Department of Management Technology \\ College of Technology, Jeddah, Technical \& \\ Vocational Training Corporation \\ P. O. Box 17608, Jeddah 21494 \\ Kingdom of Saudi Arabia
}

\begin{abstract}
The study aims to examine client opinions about the efficiency of customer relationship management (CRM)based on several areas - such as communication, building trust, meeting customer needs, and communication service qualityfor enhancing the mental image of Saudi Telecom Company (STC). The study population is all the clients of the STC. The study sample was randomly selected with a total of 507 customers.

The researcher designed a number of hypotheses, which were tested by a number of statistical techniques, such as mean, standard deviation, simple and multi-regression, ANOVA multi-analysis, and the Tooke test.

The main results of this study were as follows:

1. Client awareness was high toward the dimensions of customer relationship management (communication, trust, meeting customer needs, and quality control) and toward customer loyalty for STC.

2. There was a positive and strong correlation and a statistically significant relationship between CRM and loyalty..

3. CRM(communication, trust, meeting customer needs, and quality control) had a significant effect on achieving loyalty.

4. The statistically significant differences between STC customers in terms of achieving loyalty were attributed togenderand qualifications.

5. No statistically significant differences between STC customers were attributed to age, monthly income, profession, and (years of experience in dealing with STC).
\end{abstract}

The researcher has several recommendations:

1.STC should care about CRM based on its effectiveness by using a set of dimensions (communication, trust, meeting customer needs, and quality control) to enhance its mental image.

2. STC should measure the quality of its financial services based on customer needs to improve CRM and enhance its image.

3.STC should understand the personal characteristics of customers to ensure their conformability and satisfaction with the service offered.

4.STC should commit more time toward its customers to enhance its image.

5.STC should establish a complaint department to monitor and resolve problems to attain customer satisfactions and enhance its mental image.

6.STC should quicken its release of financial services to customers by simplifying the procedures used in order to ensure a significant relationship with its customers.

7.STC should provide specialized training programs in communication and customer service to its employees to improve their skills and guarantee efficient communication with customers.

Keywords: Customer Relationship Management, Mental Image, Communication Services Quality, Clients

\section{Introduction}

Customer relationship management (CRM) is one of the most important systems that make the customer the main focus. It helps to create an integrated database through which the company can complete all sales activities, follow-up procedures, open files for clients, and save all the events taking place on a daily basis. CRM also involves issuing reports, arranging business, inspecting the efficiency of employees in the performance of sales work, and maintaining a good relationship with the client. 
In addition, the CRM system can be fully utilized so that communication with customers can happen via e-mail, fax, and text messages, which reflects modern communication methods and the expansion of banks in terms of the number of branches and the increase in administrative divisions. Such a system is urgently needed to reduce the costs of communications and wasted time, as the system coordinates the client's affairs without the need to develop specialized staff to follow the customers, a necessity dictated by increasing administrative divisions. The customer in the concept of CRM is not a typical cline but is any legal entity or person dealing with the bank or management. The customer is a client, the employee is also a client, the supplier is a client, and all those related to the bank are customers (Maala and Ranf, 2005)

Also, in the face of considerable competition between businesses in attracting, satisfying, and retaining customers, companies must understand the services desired by customers as well as their preferences. To meet the needs of their customers is a long-term and an important commitment on the part of companies, especially as the market is under the control of the customers, not the vendors (Jones \&Suh, 2001, 16).As a result, CRM has become a modern concept discussed in many business organizations, and it focuses on establishing long-term relationships with customers. In light of the above, management must be a forward looking so that it can understand the characteristics of customers and satisfy their needs in the development of the surrounding environment such as facilities offered to the customers. Hence, the concept of CRM has emerged as an incredibly important practice and has influenced many similar concepts.

\section{Customer relationship management (CRM)}

Lamb(2001) defines CRM as a philosophy based on a set of tools, processes, and techniques that help businesses attract, retain, and develop high-value customers. CRM focuses on two key aspects of the customer: the high-value customer against the low-value customer and the customer lifecycle, from entering the relationship to leaving it.

Edelstein (2000) emphasizes that CRM in its broadest sense manages all customer interactions by using information about current and potential clients to interact more effectively with customers at all stages of a business's relationship with them. He points out that these stages represent the lifecycle of the customer, which has three stages:

- customer acquisition

- increasing the value of the customer

- retaining a good customer

At each stage, the data collected from the customer can increase the profitability of each customer and increase customer value over the defined lifecycle stages.CRM is defined by focusing on internal business processes, such as sales, marketing, and service, accompanied by data, technology, and methods. It strives for the long-term construction of relationships with customers. On this basis, CRM is a philosophy aiming to maintain and develop customers (Abu Roman, 2005).

Many researchers (Kincaid, 2003) agree that CRM focuses on business processes (marketing, sales, and services), technology, and rules to deal with customers at different stages of the customer-focused business lifecycle for sales, marketing and service purposes. Such efforts to increase customer satisfaction lead to additional customer loyalty, which directly affects the baseline of the organization. But when the organization wants to deal with customers under the philosophy of CRRM, there are questions to be answered (Ashour, 2006).

\section{CRM requirements}

CRM isa tool used to improve customer loyalty so that companies and institutions need not spend money on opening up new markets and finding new customers; instead, they can more time developing the markets and customers they already have (BuRakan, 2007).

Many priorities must be taken into account before using CRM programs, and it is necessary to change the thinking patterns and methods of implementation for all workers, from the top of the pyramid to the bottom. In order to access CRM activities, a customer marketing database must be created containing all their details, including personal information, telephone numbers, place of residence, and marital status. Such information helps companies understand their customers' needs and desires so that they become more loyal. Businesses must also have a mine of data on existing and new customers so that they have the ability to make sound marketing decisions which can enhance mental image of the companies (Al-Enezi, 2005).

CRM tools typically contain software that collects and organizes all consumer information, such as personal information, consumer feedback, suggestions, and grievances. This information is stored in large databases and helps analysts derive development ideas for the company as a whole and for the product in particular (Al-Nazir, 2009).This software is ready to use after being customized to the nature of the organization's business and usually sold at a good price. 
However, there are large organizations that prefer to work with software specifically designed to manage customer relations, this gives it the opportunity to share a large but expensive competitive advantage but it need time for programming it.

\section{What is CRM?}

Many businesses are similar in terms of the work they do, but they differ in terms of work management as well as the objectives they seek to achieve. Customers are considered to be important factors in every business. To strengthen and expand the client base, strategies must be developed to achieve this goal by having a vital customer care branch called CRM. In addition, it is a set of automated systems and technical tools that allow companies to make correct marketing decisions in terms of timing and quality to maintain a level of profitability and to develop their business. CRM systems provide valuable assistance in many areas (Reichheld, 1996). The organization must deal with all these management activities and make them compatible with its vision, mission, and customer requirements; companies must learn how to use these management techniques to satisfy the needs of their customers and enhance their mental image. All institutions, regardless of the nature of their work, think with strategic management, as they constantly seek to harness CRM and its software to serve the organization's vision, mission, and objectives, as well as to meet its customers' demands (Aqili, 2002).

\section{The benefits of CRM}

CRM refers to the methods used by a company to help it organize, study, and evaluate its relationship with its customers. The benefits to the company usually include the following: help to identify and target the best customers; increase sales quality; help plan and implement advertising campaigns with clear objectives; and help to create individual relationship with consumer. Customers should feel that the product is dedicated to them, which increases customer satisfaction. It also contributes to higher levels of customer-oriented services and provides employees with necessary information. Companies learn about the requirements and needs of their customers so that they can build a unique relationship them. CRM applications also help organizations establish valuable relationships with customers. They enable integrated sales units and customer service, and they allow employees to share information to improve sales success and provide consistent and efficient services. Sales and customer service features include managing opportunities and leadership and making customers the primary focus through knowing their aspirations and ensuring their satisfaction and loyalty to the institution. When all employees participate in collecting customer data, detecting errors and irregularities will become more effective, and any customer comment will be distributed to all the departments of the company. Thus, the company becomes more proactive in achieving customer loyalty (Greenberg,2004).

\subsection{Significance of the study}

In the context of the radical changes taking place in the competitive marketing environment, many institutions have been forced to rethink the essential role of marketing. Thus, institutions must study the purchase behavior of customers and constantly communicate with them to understand their changing needs and wishes. Knowing this about their customers will give companies an effective competitive marketing strategy, which will contribute to enhancing their image among the members of society.

\subsection{The study problem}

The Saudi Telecommunication Company (STC) is subject to very competitive conditions in the telecommunications business market, in which it is difficult to create a loyal customer base of the company, as customers know that all companies provide the same services. The marketing competition, however, lies in the mechanism of service delivery. Thus, CRM is very helpful to companies in general, the STC in particular, to achieve more success in the communication market.

\subsection{Research questions}

The current study seeks to answer the following main question:

How effective is CRM in improving the mental image of the STC among its customers?

The following sub-questions are derived from the main question:

1. What is the role of CRM in creating trust thus enhancing the mental image of the STC among its customers?

2. What is the role of CRM in meeting the needs of customers and, thus, enhancing the mental image of the STC among its customers?

3. What is the role of CRM by contacting in enhancing the mental image of the STC among customers?

4. What is the role of CRM in communicating the quality of its services, and, thus, enhancing the mental image of the STC among its customers? 


\subsection{Study hypotheses}

The first main hypothesis is the following:

HO-1: There is no statistically significant relationship between CRM as a separate variable (communication, customer trust, meeting customer needs, and quality of service communication) and enhancing the mental image at the level of $\alpha \leq 0.05$.

The following sub-hypotheses were derived from the first main hypothesis:

HO-1-1: There is no statistically significant relationship between contact with the customers and enhancing the mental image at the significance level of $(\alpha \leq 0.05)$.

HO-1-2: There is no statistically significant relationship between confidence in dealing with customers and enhancing the mental image at the significance level of $(\alpha \leq 0.05)$.

HO-1-3: There is no statistically significant relationship between meeting customer needs and enhancing the mental image at the significance level of $(\alpha \leq 0.05)$.

The second main hypothesis is the following:

Ho-2: There are no statistically significant differences between the effectiveness of CRM and enhancing the mental image at the level of importance of $(\alpha \leq 0.05)$ for STC customers due to the following variables: gender, age, academic qualification, number of years of dealing with the company, and monthly income.

\subsection{Definition of terms}

\subsubsection{CRM}

This is a marketing strategy that focuses on increasing an organization's ability to know and understand the needs of their current customers, to identify their previously preferred services and the services they will need in the future, and to improve their experience in the use of services, which lead increased customer satisfaction and loyalty(Bruhn, 2003).

\subsubsection{Meeting the needs of customers}

These activities are specialized and integrated within specific programs through which the organization's resources are exploited to satisfy the needs and requirements of the customers. These activities take specific characteristics that vary according to the requirements and needs of the customers (Zeithaml, 2000).

\subsubsection{The mental image of the institution}

The term "mental image" is a linguistic concept. Thus, the word "imitari" refers to the act of representation, and it is a mental simulation of something. A mental image in psychology is the continuation of a sensory impression due to the response of central nerve tissue.

From a marketing perspective, Harold H. Marquis defines an organization's mental image as the total self-impressions of clients about the organization.

\subsection{Study limitations}

\subsubsection{The spatial boundaries of the study}

The STC was selected because it is one of the oldest telecommunications companies in Saudi Arabia.

1.6.2 The temporal boundaries of the study

The field study took one month. Several visits were made to the STC, and various interviews were conducted with officials from some departments as well as some customers of the company. A questionnaire was also distributed to the research sample.

\section{Previous studies}

Many studies have been conducted on CRM.

Saeed (2008) conducted a study titled Factors Affecting Customer Relationship Management Performance in Arab Airlines: A Comparative Field Study. The study aimed at identifying the impact of CRM on the customer satisfaction and loyalty of various Arab airline customers, the role of technology, software, and service quality. The researcher randomly sampled from Royal Jordanian Airlines and Qatari Airways.

The study reached the following results:

- All independent variables are positively and statistically correlated with CRM performance.

- CRM performance is also impacted by independent variables (technology, market segment, distribution outlets, software, and quality of service) in relation to Qatar Airways; the technology variable has had the greatest impact on CRM performance. 
- As for Royal Jordanian Airlines, all independent variables are positively correlated, and the technology variable has had a significant impact on CRM performance.

Jaber (2008) conducted a study titled "The Impact of Customer Relationship Management on Achieving Loyalty in Jordanian Commercial Banks." The aim of this study was to demonstrate the impact of CRM on achieving loyalty in Jordanian commercial banks. The concept of CRM was addressed through certain dimensions - communication, trust, meeting needs, service quality, and price - and their impact on loyalty.

The study reached the following conclusions:

-Jordanian commercial banks achieve a high level of CRM.

-Jordanian commercial banks have a high level of loyalty.

-Each dimension of CRM (communication, trust, meeting needs, service quality, and price) affects loyalty to the bank.

-There are no statistically significant differences between the Jordanian commercial banks in their level of loyalty due to the number of years of dealing with the bank, monthly income, and the existence of account of one member of the family in the bank.

- The existence of significant differences between the banks in the level of loyalty is attributed to the name of the bank and the level of education of customers.

Ashour (2006) conducted a study titled Relationship Marketing as a Basis for Achieving Customer Loyalty in the Hotel Industry in Jordan. The objective of this study was to determine how the behavioral dimensions of the concept of relationship marketing contribute to ensuring loyalty among existing hotel customers in order to identify the most important dimensions for retaining customers. The study examined the impact of marketing dimensions on customer loyalty in the hotel industry in the Hashemite Kingdom of Jordan. A random sample of the customers of these hotels was selected, and the sample included 618 customers.

The study had the following results:

- The results showed the effect of relationship marketing on customer loyalty in these hotels. Both customer confidence and satisfaction variables explained the main change in customer loyalty.

- The results showed that each of the following dimensions of relationship marketing - customer satisfaction, barriers to change, service recovery strategies, customer-hotel relationships, and trust - directly affects customer loyalty.

- The results also showed an impact on trust and customer loyalty from the customer's point of view of the contact variable. impact on trust and customer loyalty from the customer point of view of the contact variable.

Abu Muammar (2005) conducted a study titled Measuring the Quality of Banking Service in Banks Operating in the Gaza Strip." This study aimed to identify the best standards for measuring the quality of banking services provided by banks operating in the Gaza Strip. It also aimed to highlight the importance of the different dimensions of the quality of banking service as well as to test the relationship between the quality of banking service and customer satisfaction. The study included a sample of customers of banks operating in the Gaza Strip (166).

The main results of the study are the following:

- The customer expectations should be understood in order to provide better banking services and achieve customer satisfaction. In addition, the measurement of the quality of banking services and customer awareness of them is the main way to develop and improve the quality of banking services provided to customers.

- The study showed a strong relationship with statistical significance between customer satisfaction and quality of banking service provided.

- They also concluded that that increased customer loyalty depended primarily on their assessment of the quality of banking service offered to them.

Abdullah (2002) conducted a study titled Measuring Customer Satisfaction about the Quality of Commercial Services of Islamic Financial Institutions in the State of Kuwait. The aim of this study was to identify quality of service as one of the most critical issues determining competitive position, market share, and profits. The study also pointed out that customers have more access to information, as well as customer access to the narrow stage of quality of service as a result of new and great motives generated. The study showed that service organizations can adopt the quality of service to win new customers and maintain existing customers.

The most important results of the study are as follows:

- There is a difference between service quality dimensions and what the customer expects.

- There is a relationship between service quality and achieving customer satisfaction. 


\section{Study Methodology}

\subsection{Study population}

The study population is comprised of approximately 12.5 million STC customers.

\subsection{The study sample}

The study was limited to STC customers. As for the study sample, a random sample of STC customers was selected to reach 550 customers. Therefore, 550 random questionnaires were distributed to a group of STC customers and, 507 valid questionnaires were retrieved for analysis.

\subsection{Study variables}

The definition of the conceptual framework of the variables under study is necessary to clarify the parameters and dimensions of the variables to be measured.

\subsubsection{Independent study variable}

CRM emphasizes that relationships the company and itscustomers must continue to exist, and it emphasizes the importance of customer service and developing many transactions with those customers. Companies must strive for long-term relationships with their customers tobecomemore profitable.

\subsubsection{Dependent study variable}

The mental image is what an organization offers to obtain a distinguished position in the mind of customers and, thus, achieve its market objective.

\subsection{Study design}

In order to make the subject more reliable, the information more representative and realistic, and the role of CRM in the management of a company's mental image clearer, the researcher used the analytical descriptive approach, using the applied field approach to collect data and then analyzing it and testing of hypotheses which allow more detailed study. Through this method, the researcher developed a questionnaire for data collection.

\subsection{Data collection}

Two types of data collection sources have been relied upon:

The secondary data included previous studies, masters' theses, doctoral dissertations, and periodicals related to the subject of the studyat the local, national, and international levels.

The primary dataincluded a questionnaire designed to measure the effectiveness of CRM, as represented in the variousdimensions (communication, creating trust, and meeting customer needs), in enhancing of STC customers. A quintet Likertscare was chosen for its ease of understanding and to balance its degrees. Refers to test subjects to the extent that they agree to each of the terms which consists of the proposed trend scale. The responses to the questionnaire were as follows:

\begin{tabular}{|l|l|l|l|l|}
\hline Always & often & Sometimes & Scarcely & Never \\
\hline
\end{tabular}

\subsubsection{Validity of the tool}

To verify the authenticity of the questionnaire, the researcher presented the tool in its preliminary form to a group of experts and arbitrators at the Jeddah College of Technology. The tool was also shown to referees from outside the university, and their observations were recorded. Some of the items have been reformulated and adopted in their final form, and the number of arbitrators is six.

\section{Study results}

The researcher tested the hypotheses of the study as follows:

\section{First hypothesis:}

HO-1: There is no statistically significant relationship between CRM as a separate variable (communication, creating trust, meeting customer needs, quality of service, and communication) and enhancing the mental image of the STC among its customers at the level of $\alpha \leq 0.05$.

To verify the validity of the first hypothesis, regression analysis of CRM dimensions was performed (communication, trust, meeting customer needs, and quality of communication services). 
Table 1a: Multiple regression analysis of relationship effectiveness, creating trust, meeting customer needs, and quality of communication services to enhance the mental image of the STC among its customers

\begin{tabular}{|l|c|c|c|c|}
\hline Independent variables & The link R & $\begin{array}{l}\text { Explanatory } \\
\text { variance R2 }\end{array}$ & Value of F & $\begin{array}{l}\text { Level of } \\
\text { significance F }\end{array}$ \\
\hline $\begin{array}{l}\text { communication, } \\
\text { creating trust, } \\
\text { meeting customer } \\
\text { needs, and quality of } \\
\text { communication } \\
\text { services }\end{array}$ & 0.412 & 0.170 & 25.650 & 0.0000 \\
\hline
\end{tabular}

Table 1b: Regression coefficient for independent variable

\begin{tabular}{|l|c|c|c|c|}
\hline $\begin{array}{l}\text { Independent } \\
\text { variables }\end{array}$ & $\begin{array}{l}\text { Regression } \\
\text { coefficient b }\end{array}$ & Coefficient b & Value t & $\begin{array}{l}\text { Statistical } \\
\text { significance }\end{array}$ \\
\hline Fixed & 13.202 & & 8.311 & .000 \\
\hline Connection & 1.748332 & 0.268 & 4.799 & 0.000 \\
\hline Creating trust & 0.31567 & 0.059 & 0.913 & 0.361 \\
\hline $\begin{array}{l}\text { Meeting } \\
\text { customer needs }\end{array}$ & 1.474993 & 0.269 & 3.289 & 0.001 \\
\hline $\begin{array}{l}\text { Quality of } \\
\text { communication } \\
\text { services }\end{array}$ & -1.31693 & -0.154 & -2.345 & 0.019 \\
\hline
\end{tabular}

The above table shows that the explanatory variance between independent variables reached (0.170), i.e., communication, creating trust, meeting the needs of customers and the quality of telecommunication services. It explained the value of (17\%) of achieving loyalty, the value of $F(25.650)$ and statistical significance (0.000), in which the level of acceptance of the hypothesis 0.05 , a strong relationship. This number indicates the acceptance of the main hypothesis; thus, all of the dimensions of CRM affected the company's mental image. Communication, meeting customer needs, and quality communication were the most prominent dimensions.

\section{First sub-hypothesis:}

HO-1-1: There is no statistically significant relationship between contact between the customers and STC and enhancing the mental image of the STC among its customers at significance level $(\alpha \leq 0.05)$.

Table 2: Pearson correlation coefficient between CRM in contact dimension and loyalty to STC customers

\begin{tabular}{|c|c|c|}
\hline Enhancing mental image & & \\
\hline$(* *) 349$ & Pearson correlation coefficient & \multirow[t]{3}{*}{ Connection } \\
\hline .000 & Statistical significance & \\
\hline 507 & $\mathrm{~N}$ & \\
\hline
\end{tabular}

Table 2 shows that there is a statistically significant positive relationship at the level of significance $(\alpha \leq 0.05)$ between CRM contact dimension and enhancing the mental image of the company among STC customers; the Pearson correlation coefficient is (0.349) and has a statistical significance of $(0.000)$

\section{Second sub-hypothesis}

Ho-1-2: There is no statistically significant relationship between creating trust and enhancing the mental image at the significance level of $(\alpha \leq 0.05)$.

Table 3: Pearson's correlation coefficient for the relationship between CRM management and creating trust in terms of enhancing the mental image of the STC among its customers

\begin{tabular}{|c|c|c|}
\hline Loyalty to the company & & \multirow{4}{*}{ Creating trust } \\
\hline $0.296(* *)$ & Pearson correlation coefficient & \\
\hline 0.000 & Statistical significance & \\
\hline 507 & $\mathrm{~N}$ & \\
\hline
\end{tabular}


Table 3 shows that there is a statistically significant positive correlation $(\alpha \leq 0.05)$ between CRM, trust, and enhancing the mental image ofthe STC among its customers; the Pearson correlation coefficient is (0.296) and the statistical significance is 0.000 ).

Third sub-hypothesis

Ho-1-3: There is no statistically significant relationship between meeting customer needs and enhancing the mental image of the STC among its customers at the significance level of $(\alpha \leq 0.05)$.

Table 4: Pearson's correlation coefficient on the relationship between CRM after satisfying customer needs and enhancing the mental image of the STC among its customers

\begin{tabular}{|c|c|c|}
\hline Loyalty to the company & & \multirow{4}{*}{ Meeting needs } \\
\hline $0.362(* *)$ & Pearson correlation coefficient & \\
\hline 0.000 & Statistical significance & \\
\hline 507 & $\mathrm{~N}$ & \\
\hline
\end{tabular}

Table 4 shows that there is a statistically significant positive correlation $(\alpha \leq 0.05)$ between CRM after satisfying customer needs and enhancing the mental image to customers of Saudi Telecom Company; the Pearson correlation coefficient is (362).

Table 5: Pearson's correlation coefficient on the relationship between CRM in the quality of telecom services and enhancing the mental image of the STC among its customers

\begin{tabular}{|l|l|l|}
\hline \multicolumn{1}{|c|}{ Loyalty to the company } & \multicolumn{1}{|c}{ Quality service } \\
\hline $0.252(* *)$ & Pearson correlation coefficient & \\
\hline 0.000 & Statistical significance & \\
\hline 507 & $\mathrm{~N}$ & \\
\hline
\end{tabular}

Table 5 shows that there is a statistically significant positive correlation at $(\alpha \leq 0.05)$ between CRM in the quality of services and enhancing the mental image of theSTC among its customers; the Pearson correlation coefficient is (252), and the statistical significance is (0.000). As a result, the null hypothesis (the first main hypothesis) is rejected as well as and the sub-hypotheses derived from it. The second hypothesis is accepted, and it provides a statistically significant relationship between the dimensions of CRM and enhancing mental image of STC among its customers. This confirms that CRM is highly effective in strengthening the relationship between the company and its customers.CRM enables communication companies to market their services though emphasizing the importance of the customer as a main hub for the company. Therefore, CRM ensures the importance of keeping customers in the context of intense local and international competition, and to work to meet his needs of various banking services and work to satisfy it in the optimum and competitive advantages of high quality and high specifications.

\section{The second main hypothesis:}

Ho-2: There are no statistically significant differences between the effectiveness of CRM and enhancing the mental image of the STC among its customers at the level of importance of $(\alpha \leq 0.05)$ due to the following variables: gender, age, academic qualification, number of years of dealing with the company, and monthly income.

To test the significance of the statistical differences between the arithmetic averages according to the gender variable, T-test was used and (Table 6) illustrates the results

Table 6: The t-test demonstrating the effectiveness of the gender variable on the relationship management of STC's customers investigated at the level of enhancing the company 's mental image

\begin{tabular}{|c|c|c|c|c|}
\hline Gender & Number & Value of $F$ & $\mathrm{~T}$ & $\begin{array}{c}\text { Statistical } \\
\text { significance }\end{array}$ \\
\hline Male & 330 & 0.496168 & 7.924426 & 0.005068 \\
\hline Female & 177 & & & \\
\hline
\end{tabular}

Table 6 shows that there are significant differences between the averages between the estimates of the sample members for the enhancing the mental image of STC among its customers according to the gender variable; the value of $\mathrm{T}$ is (0.496168)m and the significance value is $(0.005068)$.

In order to demonstrate the significance of the statistical differences between the arithmetic averages according to the sample variables (age, educational qualification, number of years of dealing with the company, and monthly income), variance analysis was used at the level of allegiance (Table 7). 
Table 7: Results of multi-variance analysis on the effectiveness of (age, educational qualification, number of years of dealing with company, and monthly income) of CRM in enhancing the mental image of the STC among its customers in Saudi Arabia

\begin{tabular}{|c|c|c|c|c|c|c|}
\hline & & $\begin{array}{l}\text { Total } \\
\text { squares }\end{array}$ & $\begin{array}{l}\text { Degrees of } \\
\text { freedom }\end{array}$ & $\begin{array}{c}\text { Average } \\
\text { squares }\end{array}$ & Value $(\mathrm{P})$ & $\begin{array}{l}\text { Statistical } \\
\text { significance }\end{array}$ \\
\hline \multirow[b]{3}{*}{ Age } & $\begin{array}{c}\text { Between } \\
\text { groups }\end{array}$ & 0.184 & 3 & 0.061 & 0.302 & 0.824 \\
\hline & $\begin{array}{l}\text { Within } \\
\text { groups }\end{array}$ & 102.122 & 503 & 0.203 & & \\
\hline & Total & 372.9034 & 506 & & & \\
\hline \multirow{3}{*}{$\begin{array}{c}\text { Academic } \\
\text { qualifications }\end{array}$} & $\begin{array}{c}\text { Between } \\
\text { groups }\end{array}$ & 10.934 & 5 & 2.187 & 11.990 & $* 0.000$ \\
\hline & $\begin{array}{l}\text { Within } \\
\text { groups }\end{array}$ & 91.372 & 501 & 0.182 & & \\
\hline & Total & 102.306 & 506 & & & \\
\hline \multirow{3}{*}{$\begin{array}{l}\text { Number of } \\
\text { years of } \\
\text { dealing with } \\
\text { the company }\end{array}$} & $\begin{array}{c}\text { Between } \\
\text { groups }\end{array}$ & 1.200 & 5 & 0.240 & 1.189 & 0.313 \\
\hline & $\begin{array}{l}\text { Within } \\
\text { groups }\end{array}$ & 101.106 & 501 & 0.202 & & \\
\hline & Total & 102.306 & 506 & & & \\
\hline \multirow{3}{*}{$\begin{array}{c}\text { Monthly } \\
\text { income }\end{array}$} & $\begin{array}{c}\text { Between } \\
\text { groups }\end{array}$ & 1.161 & 5 & 0.232 & 1.150 & 0.333 \\
\hline & $\begin{array}{l}\text { Within } \\
\text { groups }\end{array}$ & 101.146 & 501 & 0.202 & & \\
\hline & Total & 102.306 & 506 & & & \\
\hline
\end{tabular}

The table shows the following:

- There were no statistically significant differences at the level of significance $(\alpha \leq 0.05)$ due to the age of the customer; the value of $F$ is (0.302), and the statistical significance is (0.824).

- There are differences of statistical significance at the level of significance $(\alpha \leq 0.05)$ attributed to the educational qualification, where the value of $\mathrm{F}(11.990)$ and the statistical significance is $(0.000)$. To show the marital differences between the arithmetical averages, the Tukey method was used, as shown in Table 8.

- There were no statistically significant differences at the level of significance $(\alpha \leq 0.05)$ due to customer age, where the value of $\mathrm{F}$ is (0.302) and the statistical significance is (0.824).

- There were no statistically significant differences at the level of significance $(\alpha \leq 0.05)$ due to the number of years of dealing with the STC, where the value of F is (1.899) and the statistical significance is $(0.313)$.

- There are no statistically significant differences at the level of significance $(\alpha \leq 0.05)$ due to monthly income, where the value of $\mathrm{F}$ is (1.150) and the statistical significance is (0.333).

Table 8: Tukey distance comparisons for the effectiveness of variable educational qualifications on the effectiveness of CRM in enhancing the mental image of STC among its customers

\begin{tabular}{|c|c|c|c|c|c|c|c|}
\hline & $\begin{array}{l}\text { Arithmetic } \\
\text { average }\end{array}$ & $\begin{array}{l}\text { Intermediate } \\
\text { degree }\end{array}$ & $\begin{array}{l}\text { Diploma after } \\
\text { intermediate } \\
\text { degree }\end{array}$ & $\begin{array}{l}\text { Secondarysta } \\
\text { ge }\end{array}$ & $\begin{array}{c}\text { Diploma after } \\
\text { secondarystag } \\
\text { e }\end{array}$ & Academic & Postgraduate \\
\hline $\begin{array}{c}\text { Intermediate } \\
\text { degree }\end{array}$ & 3.2118056 & & & & & & \\
\hline $\begin{array}{c}\begin{array}{c}\text { Diploma after } \\
\text { intermediate } \\
\text { degree }\end{array} \\
\end{array}$ & 3.9199561 & $0.70815\left(^{*}\right)$ & & & & & \\
\hline Secondarystage & 3.7631579 & $0.55135\left(^{*}\right)$ & $\begin{array}{c}- \\
.15680 \\
\end{array}$ & & & & \\
\hline $\begin{array}{l}\text { Diploma after } \\
\text { secondarystage }\end{array}$ & 3.8436853 & $0.63188(*)$ & $\begin{array}{c}- \\
0.7627 \\
\end{array}$ & 0.08053 & & & \\
\hline Academic & 3.8684641 & $0.65666(*)$ & $\begin{array}{c}- \\
0.05149 \\
\end{array}$ & 0.10531 & 0.02478 & & \\
\hline Postgraduate & 4.0454545 & $0.833659(*)$ & .12550 & 0.28230 & 0.20177 & 0.17699 & \\
\hline
\end{tabular}

Tukey HSD * 
The mean difference is significant at the 0.05 level.

Table 8 shows statistically significant differences at the level of significance (0.05) among the following categories of customers:

- Customers who achieve a diploma after the intermediate degree and between intermediate customers with an average score, and for the favor of diploma after intermediate holders because their arithmetic mean is higher.

- Between the secondary and intermediate grades' customers and in favor of the secondary degree campaign because their arithmetic mean is higher.

- Among customers who achieve a diploma after the secondary stage and intermediate degree holders, and in favor of diploma after secondary holders because their arithmetic mean is higher.

- Between undergraduate and intermediate degree holders, and for university degree holders because their average arithmetic is higher.

\section{Conclusion}

CRM affects several aspects related to acquiring competitive marketing advantages because the process of building long-term relationships with customer sensures they stay with institution, which results in continued revenues and costeffectiveness.CRM is the way to achieve satisfaction and create a good mental image of the institution, which can be obtained only through a good and strong relationship between the institution and its customers. As a result of these relationships, customers become permanent customers of the organization, and, thus, the customer defends the organization and its products. This turns into an important source of attracting more customers instead of directing them to other competing telecommunication companies. STC is one of the largest telecommunications companies in the Saudi Arabian telecom market, which is known for its significant developments and achievements in acquiring a strong position as compared to the position it had at its establishment. The STC has improved its mental image among its customers through contacting them, listening to them, and striving to maintain and establish a long relationship with them. All of this has helped the company retain its existing customers for a long time, win new customers, and, thus, manage its mental image in a positive way. As a result, it has obtained competitive advantages over competing telecommunication companies.

\section{References}

Abdullah, Sh. (2002).Measuring customer satisfaction with the quality of business services of Islamic financial institutions in the State of Kuwait (Unpublished master thesis), Ain Shams University, Egypt.

Abu Muammar, F. (2005).Measuring the quality of banking service in banks operating in the Gaza Strip. Journal of the Islamic University, Human Studies Series, 13(1), 77-105.

Al Enezi, F. (2005). Customer relations management: programs, investment, and culture. Retrieved from http://www.bab.com/articles/full_article.cfm?id=8414Line).

Al Nazir, N. (2009).The impact of marketing with relations and treatment motives on the customers' loyalty to the organization. Applied study on a sample of Jordanian trade banks' customers in Amman(Unpublished master thesis), Middle East University for Higher Studies, Amman, Jordan.

Aqili, A. (2002).Customer relations' management remains its energy with technologies. Retrieved from http//:www.arabit.com.sa/aArticle_118_ARA_HTML.htm.

Ashour, L. (2006).Relationship marketing as a basis for achieving customer loyalty in the hotel industry in Jordan (Unpublished doctoral dissertation), Amman Arab University, Amman, Jordan.

Bu,Rakan (2007).A closer look in marketing. Retrieved fromhttp://www.ibtesama.com/vbljan2007.onLine.

Edelstein, H. (2000) Building profitable customer relationships with data mining. In: (SCN Education B.V. (Ed, 2001).

Greenberg, P. (2004).CRM at the speed of light: essential customer strategies for the 21st century (3rd ed.). Eneryville, CA: McGrawHill/Osborne.

Jaber, J.,\& Rashad, M. (2008).The impact of customer relationship management on achieving loyalty in Jordanian commercial banks (Unpublished master thesis), Al-Bayt University, Mafraq, Jordan.

Jones, M., \& Suh, J. (2001). Transaction, specific satisfaction and overall satisfaction: an empirical analysis. Journal of Services Marketing, 14(2), 147-159.

Kincaid, W. M. (2003). Promotion: products, services and ideas(6th ed.). Columbus, Ohio: Bell and Howell Company.

Lam, R., \& Burton, S. (2006). SME banking loyalty and disloyalty:a qualitative study in HongKong. International Journal of Bank Marketing, 24(1), 37-52.

Maala, N., \& Ranf, T. (2005).Marketing basics: analytical introduction. WaelPublishing House, Amman

Reichheld.F, (1996).The loyalty effect: the Hidden forces before growth. Profit and lasting value. Boston. Ma: Harvard Business School Press.

Saeed, M.,\&Ayat, M. (2008).Factors affecting the performance of customer relationship management in Arab airlines: a comparative field study (Unpublished master thesis), Al-Bayt University, Mafraq, Jordan. 